Comparative Study of the Gasification of Coal and Its Macerals and Prediction of the Synergistic Effects Under Typical Entrained-Bed Pulverized Coal Gasification Conditions

Peng Jiang, Dengting Guo, Xiang Luo, Mengxia Xu, Tao Wu

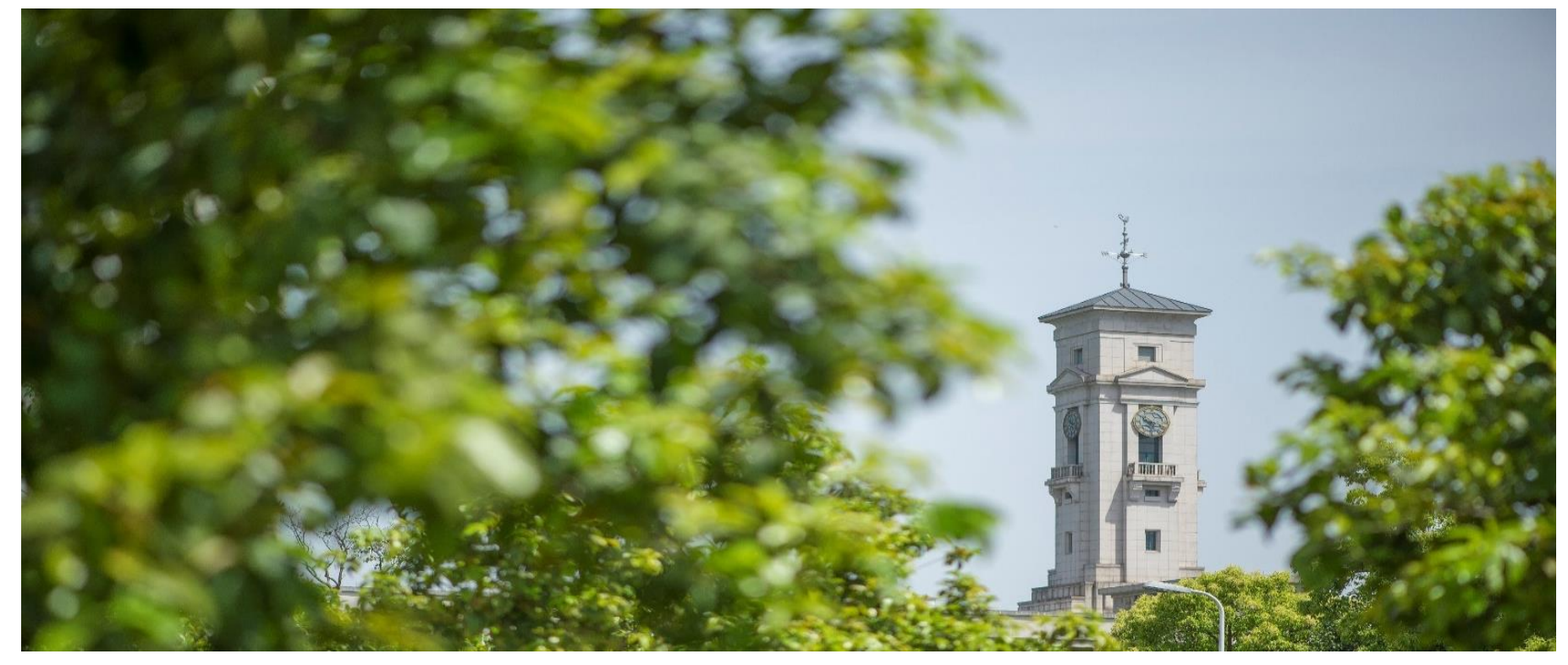


University of Nottingham Ningbo China, 199 Taikang East Road, Ningbo, 315100, China

First published 2020

This work is made available under the terms of the Creative Commons Attribution 4.0 International License:

http://creativecommons.org/licenses/by/4.0

The work is licenced to the University of Nottingham Ningbo China under the Global University Publication Licence:

https://www.nottingham.edu.cn/en/library/documents/researchsupport/global-university-publications-licence.pdf Nottingham 


\title{
Comparative study of the gasification of coal and its macerals and prediction of the synergistic effects under typical entrained-bed pulverized coal gasification conditions
}

Peng Jiang ${ }^{1}$, Dengting Guo ${ }^{1}$, Xiang Luo ${ }^{1,2}$, Mengxia $\mathrm{Xu}^{1,2}$, Tao $\mathrm{Wu}^{1,2^{*}}$

${ }^{1}$ Key Laboratory of Clean Energy Conversion Technologies, The University of Nottingham Ningbo China, Ningbo 315100, PR China

${ }^{2}$ New Materials Institute, The University of Nottingham Ningbo China, Ningbo 315100, PR China

*Corresponding author: Tao Wu, Tao.Wu@ nottingham.edu.cn

\begin{abstract}
This research is focused on the gasification performance of coal and its corresponding macerals as well as on the interactions among macerals under typical gasification conditions by Aspen Plus modelling. The synergistic coefficient was employed to show the degree of interactions, while the performance indicators including specific oxygen consumption (SOC), specific coal consumption (SCC), cold gas efficiency (CGE) and effective syngas $\left(\mathrm{CO}+\mathrm{H}_{2}\right)$ content were used to evaluate the gasification process. Sensitivity analysis showed that the parent coal and its macerals exhibited different gasification behaviours at the same operating conditions, such as the SOC and SCC decreased in the order of Inertinite> Vitrinite >Liptinite, whereas CGE is changed in the order of Liptinite >Vitrinite> Inertinite. The synergistic coefficients of SOC and SCC for the simulated coals were in the range of 0.94 to 0.97, whereas the synergistic coefficient of CGE was from 1.05 to 1.13. Moreover, it was found that the relationships between synergistic coefficients of gasification indicators were correlated well with maceral contents. In addition, the increase of temperature was
\end{abstract}


found promoting the synergistic coefficients slightly, whilst at an oxygen to coal (OTC) mass ratio of 0.8 and a steam to coal (STC) mass ratio of 0.8, the highest synergistic coefficients were obtained.

Keywords: Coal macerals; entrained-bed gasification; synergistic effects; Aspen Plus

\section{Introduction}

According to IEA report 2017, coal constitutes approximately $27 \%$ of the global energy mix. It is estimated that the quantity of coal for power generation will contribute to $55 \%$ of China's energy demand in the next five years [1] and coal will still continue playing a major role in meeting human being's energy demand worldwide [2,3]. Coal gasification, which converts solid fuels into a gaseous product at elevated pressure and temperature, is considered the most effective method to realize the clean, efficient and economical utilization of coal [4-6]. Currently, there are three major types of gasifier that have been commercially used worldwide, i.e., fixed-bed gasifier, fluidized-bed gasifier and entrained-bed gasifier. Their unique characteristics are summarized in the literature [7]. Entrained-bed gasifiers have the advantages of dealing with any type of coals with high carbon conversion and high throughput $[8,9]$. Shell entertained-bed gasifier is one of the representative gasification technologies and takes up a significant portion of installed capacities in the world [7, 8].

According to the classification of International Commission for Coal Petrology (ICCP), macerals are divided into three groups and named as vitrinite, liptinite and inertinite [10]. The determination of different groups lies in the distinguishable colour under reflective light and morphology of the macerals. Except for the differences in appearance, maceral groups differ in their chemical composition, which brings distinct technical performances and therefore affects the burnout of the 
fuel $[11,12]$. Therefore, an insight into macerals is the most fundamental step to understand the properties of the parent coal and subsequently, the efficiency of maceral-enriched feedstock [13].

In the past few decades, experimental studies on the structural transformation of macerals and the change in chemical reactivity during pyrolysis/gasification have attracted significant attention [1318]. For example, Sun et al. [14] compared the structural variations of the macerals before and after pyrolysis and found that vitrinite led to the yield of more aliphatic $\mathrm{C}-\mathrm{H}$ and lowered aromaticity than inertinite. It is reported $[13,16]$ that at a short gasification residence time $(10 \mathrm{~s})$, the conversion is in the order of liptinite> vitrinite> inertinite, while at a long residence time (200 s), the extent of gasification was found to be inertinite> vitrinite>liptinite. Moreover, Sun et al. [17] conducted $\mathrm{CO}_{2}$ gasification of vitrinite char and inertinite char in a pressurized thermobalance at a temperature up to $950{ }^{\circ} \mathrm{C}$ and reported that the vitrinite char was more reactive than the inertinite char with or without a catalyst. However, more recently, Wang et al. [18] stated that the gasification reactivity of vitrinite was lower than that of inertinite under $\mathrm{CO}_{2}$ gasification atmosphere.

The interaction between macerals during thermal processing is of significance for the basic understanding of the coal chemistry, developing new coal utilization technology and improving thermal efficiency. Sun et al. [19] compared the volatile yield of the pyrolysis of parent coal and its macerals and concluded the existence of synergism among macerals. Chang et al. [20] also studied the interaction during the pyrolysis of inertinite and vitrinite using FTIR, TG and fixed bed reactor and gave a thorough explanation of the interaction mechanisms at molecule levels. Later, the synergistic effect of macerals during hydropyrolysis was also reported by Sun et al. [21], whereas the maximum synergism reached $14.1 \%$ at $500{ }^{\circ} \mathrm{C}$ and $3 \mathrm{MPa}$. Zubkova et al. [22] also explored the interactions of macerals during carbonization and obtained a denser coke than theoretical expectation. 
To date, researchers have conducted a significant amount of work on the understanding of the reactivity of macerals during pyrolysis and gasification as well as on the determination of the interactions between macerals during pyrolysis, but few of them have paid attention to the differences of gasification products, cold gas efficiency, syngas content, specific oxygen consumption and specific coal consumption among macerals and parent coal. Besides, the synergistic effects of macerals during gasification have rarely been investigated. Moreover, the influence of process operating parameters on the synergistic effect has not been discussed although Aspen Plus has been widely applied in the study of solid fuel gasification systems [23-26].

In this study, the comparatively study of the gasification behaviours of the parent coal and its maceral components under actual entrained-bed gasification conditions was carried out by using Aspen Plus. The quantitative evaluation of the interactions between macerals as well as sensitivity analyses were performed. Besides, the relationship between the synergistic coefficient and maceral contents was investigated. In addition, impacts of typical operating parameters on the interactions among macerals were revealed.

\section{Methodology}

Shell coal gasification technology is a commercial technology that is capable of dealing with a large range of coals at a high energy conversion efficiency [7, 27]. The Aspen Plus diagram of a Shell gasification process is illustrated in Fig.1. Milled coal is dried to 5\% moisture content and mixed with $\mathrm{N}_{2}$ in lock-hopper before being fed into the gasifier. The coal is gasified under the conditions of medium pressure using 95 vol\% oxygen derived from a stand-alone air separation unit [27]. The commercial operating pressure is around 4.0 MPa, and the gasification temperature is in the range of 
1350 to $1550{ }^{\circ} \mathrm{C}$. The steam to coal mass ratio varies from 0.01 to 0.16 and the feed oxygen to coal mass ratio is in the range of 0.5 to 1.1 . The reactions considered in this study are the ones being considered in the literature [28]. The gas product from the gasifier is quenched by recirculated cold syngas to a temperature of around $900^{\circ} \mathrm{C}$ [29]. After quench, the heat of the raw gas is recovered by a syngas cooler generating steam for power generation. The syngas is sent to a candle filter to remove particulate matters.

The gasification process is mainly simulated by using a combination of RYIELD and RGIBBS modules in Aspen Plus. The function of RYIELD model is to convert the unconventional coal into standard components such as $\mathrm{H}_{2}, \mathrm{~N}_{2}, \mathrm{O}_{2}, \mathrm{~S}, \mathrm{H}_{2} \mathrm{O}, \mathrm{Cl}_{2}$ and ash, and their yield distribution is programmed using FORTRAN codes according to the ultimate analysis of coal [30-32]. The RGIBBS is a phase and chemical equilibrium model based on Gibbs free energy minimization and is commonly employed to model coal pyrolysis and gasification in the Shell gasifier [33]. In addition, the PR-BM method is used to calculate the thermodynamic properties of materials stream [34].

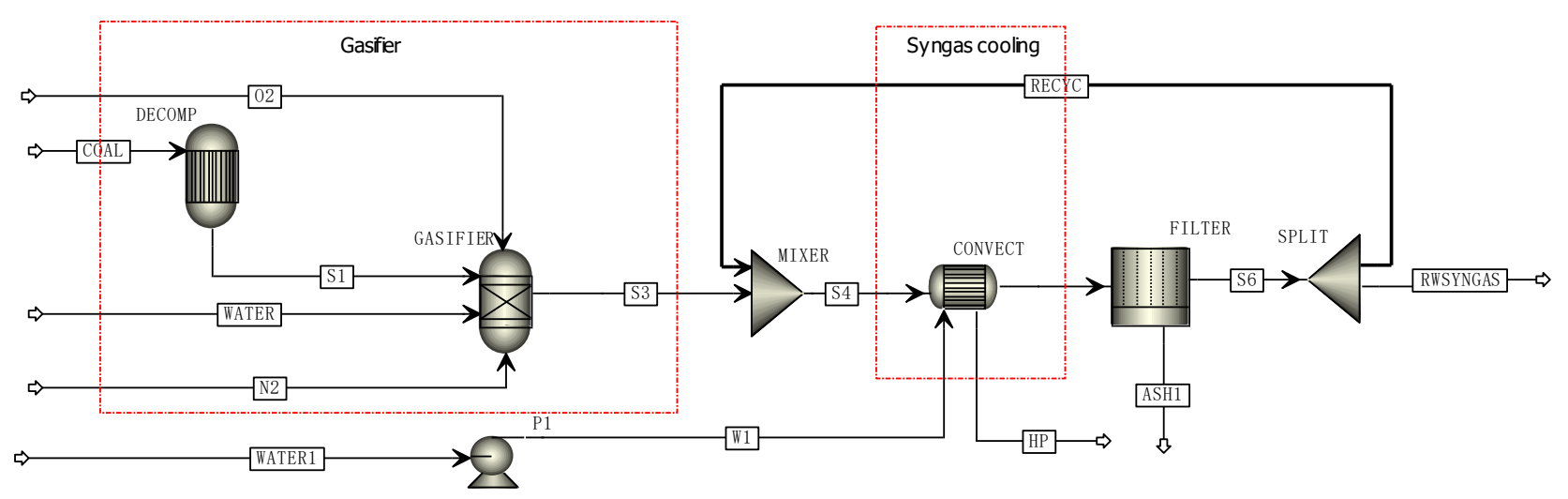

Fig.1 Aspen plus flow sheet of Shell coal gasification process

In order to understand the gasification behaviours of the parent coal and its corresponding macerals, the existing analytical data of Pingshuo bituminous coal and its macerals were taken as the feedstock 
for this study. Maceral groups are separated based on their density difference using $\mathrm{ZnCl}_{2}$ liquid [35].

The composition, together with the petrographic analysis of the feed coal and maceral groups, are listed in Table 1. The study of interaction among macerals is based on the petrological features of the Pingshuo Bituminous coal, which is shown in Table 2 [35]. The main process parameters and conditions of the gasification of the coal and its macerals are shown in Table 3.

Table 1 Ultimate and petrographic analyses of Pingshuo Bituminous coal [35]

\begin{tabular}{|c|c|c|c|c|}
\hline & Coal & Vitrinite sample & Inertinite Sample & Liptinite Sample \\
\hline \multicolumn{5}{|c|}{ Ultimate analysis/(dry, wt $\%)$} \\
\hline $\mathrm{C}$ & 62.003 & 78.322 & 83.077 & 70.912 \\
\hline $\mathrm{H}$ & 4.093 & 5.311 & 3.883 & 7.269 \\
\hline $\mathrm{O}$ & 10.119 & 13.406 & 9.697 & 16.600 \\
\hline $\mathrm{N}$ & 1.111 & 1.218 & 0.647 & 0.819 \\
\hline S & 0.334 & 0.569 & 0.745 & 0.800 \\
\hline Ash & 22.341 & 1.174 & 1.951 & 3.600 \\
\hline \multicolumn{5}{|c|}{ Petrographic analysis/(daf,wt $\%)$} \\
\hline Vitrinite & 69.8 & 95.2 & 2.3 & 2.3 \\
\hline Inertinite & 23.1 & 3 & 96.7 & 1.4 \\
\hline Liptinite & 7.1 & 1.8 & 1 & 96.3 \\
\hline
\end{tabular}

Table 2 Mass composition of simulated coal (wt\%) [35]

\begin{tabular}{llll}
\hline \hline Simulated coal no. & Vitrinite & Inertinite & Liptinite \\
\hline 1 & 26.67 & 6.67 & 66.66 \\
2 & 17.29 & 21.74 & 60.87 \\
3 & 12.95 & 29.08 & 57.97 \\
4 & 34.84 & 4.34 & 60.82 \\
5 & 25.79 & 16.11 & 58.09 \\
6 & 29.63 & 33.37 & 30 \\
\hline
\end{tabular}




\begin{tabular}{llll}
\hline 7 & 38.75 & 3.22 & 58.03 \\
8 & 44.45 & 18.53 & 37.03 \\
9 & 34.28 & 25.72 & 40 \\
\hline \hline
\end{tabular}

Table 3 Main conditions for the gasification simulation [36, 37]

\begin{tabular}{ll}
\hline \hline Item & Values \\
\hline The feed flow rate for Coal and macerals, $\mathrm{kg} / \mathrm{s}$ & 10 \\
$\mathrm{~N}_{2}$ flow rate, $\mathrm{kg} / \mathrm{s}$ & 0.717 \\
Gasification pressure, $\mathrm{MPa}$ & 4.0 \\
Temperature range, ${ }^{\circ} \mathrm{C}$ & $1350-1550$ \\
Steam to coal (STC) mass ratio: & $0.01-0.16$ \\
Oxygen to coal (OTC) mass ratio: & $0.5-1.1$ \\
Oxygen feed composition (vol\%): & \\
$\quad \mathrm{O}_{2}$ & 95.0 \\
$\mathrm{~N}_{2}$ & 1.0 \\
$\quad$ Ar & 4.0 \\
\hline \hline
\end{tabular}

\section{System evaluation indicators}

The evaluation indicators for the gasification of coal and its macerals mainly include specific oxygen consumption, specific coal consumption, syngas lower heating value (LHV), cold gas efficiency and the content of effective syngas $\left(\mathrm{CO}+\mathrm{H}_{2}\right)$ in the product gas.

Cold gas efficiency (CGE, \%) is defined as [38],

$$
\text { CGE }(\%)=\frac{\text { LHV of the syngas } \times \text { syngas flow rate }}{\text { LHV of feedstock } \times \text { flow rate }} \times 100
$$

The LHV $\left(\mathrm{MJ} / \mathrm{Nm}^{3}\right)$ of the syngas is calculated as [39],

$$
L H V=\frac{\left(\mathrm{CO} \times 126.36+\mathrm{H}_{2} \times 107.98+\mathrm{CH}_{4} \times 358.18\right)}{1000}
$$


Where $\mathrm{CO}, \mathrm{H}_{2}, \mathrm{CH}_{4}$ is the volume fraction in the production of gas from the gasification.

The higher heating value (HHV) of coal/macerals is obtained by the correlation proposed by Channiwala et al.[40],

$$
\mathrm{HHV}_{\text {coal }}=349.1 \mathrm{Zc}+1178.3 Z_{H^{-}} 103.4 Z_{O^{-}}-15.1 Z_{N}+100.5 Z_{S}
$$

The LHV of the coal is predicted using the following equation [41],

$$
L H V_{\text {coal }}=H H V_{\text {coal }}-21.978 Z_{H}
$$

Where $\mathrm{Z}_{\mathrm{C}}, \mathrm{Z}_{\mathrm{H}}, \mathrm{Z}_{\mathrm{O}}, \mathrm{Z}_{\mathrm{N}}$ and $\mathrm{Z}_{\mathrm{S}}$ are the mass concentration of the carbon, hydrogen, oxygen, nitrogen and sulfur in the feedstock, respectively, as shown in Table 1.

The specific oxygen consumption (SOC) is defined as the amount of oxygen consumed per volume of effective syngas production.

$$
\mathrm{SOC}=\mathrm{Nm}^{3} \mathrm{O}_{2} /\left(\mathrm{CO}+\mathrm{H}_{2}\right) \mathrm{kNm}^{3}
$$

The specific coal consumption (SCC) represents the ratio of coal consumption or macerals consumption to the volume of effective syngas generated in the gasification.

$$
\mathrm{SCC}=\mathrm{kg} \mathrm{coal} /\left(\mathrm{CO}+\mathrm{H}_{2}\right) \mathrm{kNm}^{3}
$$

Synergetic coefficient $\left(a_{\mathrm{ij}}\right)$ accounts for the interactions among macerals is determined as following [35]:

$$
a_{i j}=\frac{x_{i j}}{y_{i j}}
$$

Where $i$ is the number of simulated coals, $i=1$ to $9 ; j$ stands for the gasification products and evaluation parameters, for example, $j$ can be the mole fraction of $\mathrm{CO}, \mathrm{H}_{2}$ and the value CGE, etc. $x$ is the 
numerical value of gasification products and the evaluation indicators calculated from Aspen plus. The physical meaning of $y$ stands for theoretical values without considering interaction, which is obtained by the addition algorithm taking into account the mass weight fraction of each maceral in the simulated coal as tabulated in Table 2 .

$$
\begin{aligned}
& y_{i j}=\sum_{k=1}^{3} z_{i k} y_{k j} \\
& \sum_{k=1}^{3} z_{k}=1
\end{aligned}
$$

Where $z$ is the mass concentration of the $k^{\text {th }}$ independent macerals in the $i^{\text {th }}$ simulated coal.

\section{Results and Discussion}

Based on the data shown in Table 1 and Table 2, together with the simulation conditions indicated in Table 3, the gasification performance of each type of feedstock is determined and compared under the same operating conditions. For comparison, the benchmark operating parameters are as follows: gasification temperature is at $1450{ }^{\circ} \mathrm{C}$, the OTC and STC values are 0.8 and 0.08 , respectively.

\subsection{Simulation results}

To validate the simulation, the comparison of the syngas composition from the gasifier between the simulation results and industrial data described in the reference [36] is shown in Table 4. As shown in Table 4, the simulation values are agreeable well with the industrial data [36], which demonstrates the reliability of this model.

Table 4 Comparison of the simulation values and industrial data

\begin{tabular}{lll}
\hline \hline Syngas & Industrial Data & Simulation Value \\
Composition/vol\% & & \\
\hline
\end{tabular}




\begin{tabular}{lll}
\hline $\mathrm{H}_{2}$ & 30.0 & 29.9 \\
$\mathrm{CO}$ & 60.3 & 60.9 \\
$\mathrm{CO}_{2}$ & 1.6 & 1.3 \\
$\mathrm{H}_{2} \mathrm{~S}$ & 1.2 & 1.2 \\
$\mathrm{COS}$ & 0.1 & 0.1 \\
$\mathrm{~N}_{2}$ & 3.6 & 3.6 \\
$\mathrm{Ar}$ & 1.1 & 1.1 \\
$\mathrm{H}_{2} \mathrm{O}$ & 2.0 & 1.8 \\
Others & 0.1 & 0.1 \\
\hline
\end{tabular}

The syngas composition and performance indicators for coal and its macerals are summarized in Table 5. It can be seen that $\mathrm{H}_{2}$ and $\mathrm{CO}$ are the two main gases taking up most volume fractions up to $95 \mathrm{vol} \%$ of the gas product. The $\left(\mathrm{CO}+\mathrm{H}_{2}\right)$ content varies in the order of Vitrinite $(94.98 \%) \approx$ Inertinite $(94.67 \mathrm{vol} \%)>$ liptinite $(93.87 \mathrm{vol} \%)>$ parent coal $(89.52 \mathrm{vol} \%)$. As for the CO volume fraction, Inertinite possesses the highest volume fraction of 67.36 vol\%, followed by Vitrinite of 63.20 vol\% and Liptinite of 56.71 vol\%. However, for $\mathrm{H}_{2}$, the order is changed to Liptinite> Vitrinite> Inertinite. This is expected because based on ultimate analysis, Liptinite and Inertinite have the highest hydrogen and carbon content, which is higher than that of the parent coal. The indicators of SOC and SCC illustrate that the parent coal consumes the most amount of oxygen and fuel to produce the same amount of syngas, while the pure Liptinite and Vitrinite require the least amount of oxygen and fuel to produce the same amount of syngas. This is mainly because the feedstock of parent coal contains a considerable amount of ash $(22.24 \mathrm{wt} \%)$ as compared with a small portion (less than $3.6 \mathrm{w} \%$ ) of minerals in their respective maceral components. In addition, due to the less containment of hydrogen and carbon in the ultimate analysis of Liptinite, the need for oxygen and coal to generate the same 
amount of effective syngas displays a corresponding reduction trend. With regard to CGE, the Liptinite $(84.27 \%)$ is superior to Vitrinite $(82.12 \%)$, parent coal $(75.61 \%)$ and Inertinite $(71.48 \%)$. The reason for this order can be attributed to a higher syngas LHV value calculating from Eqs.(2) of the Liptinite than other components. Subsequently, the CGE of Liptinite achieves a better performance based on Eqs. (1). Although the LHV value of the syngas derived from the Inertinite is greater than that of syngas derived from parent coal from Table 5, the LHV value of Inertinite feedstock is greater than that of the parent coal resulting in a relatively smaller CGE of the Inertinite.

Table 5 Syngas composition (dry basis) and performance evaluation indicators for coal and its macerals

\begin{tabular}{|c|c|c|c|c|}
\hline Composition & Coal /Vol\% & Vitrinite /Vol\% & Inertinite /Vol\% & Liptinite /Vol\% \\
\hline $\mathrm{CH}_{4}$ & 0.00563 & 0.196 & 0.145 & 0.026 \\
\hline $\mathrm{H}_{2}$ & 26.81 & 31.78 & 27.31 & 37.16 \\
\hline $\mathrm{CO}$ & 62.71 & 63.20 & 67.36 & 56.71 \\
\hline $\mathrm{CO}_{2}$ & 4.73 & 0.22 & 0.25 & 1.7 \\
\hline $\mathrm{H}_{2} \mathrm{~S}$ & 0.12 & 0.166 & 0.236 & 0.23 \\
\hline COS & 0.012 & 0.014 & 0.025 & 0.015 \\
\hline $\mathrm{N}_{2}$ & 5.27 & 4.15 & 4.37 & 3.88 \\
\hline $\mathrm{Ar}$ & 0.33 & 0.26 & 0.29 & 0.25 \\
\hline Others & 0.02 & 0.014 & 0.014 & 0.029 \\
\hline \multicolumn{5}{|l|}{ Performance evaluation } \\
\hline Syngas flow rate, $\mathrm{Nm}^{3} / \mathrm{h}$ & 60507.9 & 77632.2 & 69908.3 & 79877.7 \\
\hline SOC & 373.03 & 274.03 & 305.31 & 269.48 \\
\hline $\mathrm{SCC}$ & 651.32 & 478.47 & 533.07 & 470.52 \\
\hline Syngas LHV, MJ/h & 651799.91 & 887633.22 & 801249.79 & 889109.73 \\
\hline CGE, $\%$ & 75.61 & 82.12 & 71.78 & 84.27 \\
\hline$\left(\mathrm{CO}+\mathrm{H}_{2}\right)$, vol\% & 89.52 & 94.98 & 94.67 & 93.87 \\
\hline
\end{tabular}


Table 6 presents the summary of Aspen plus simulation and performance indicators of the simulated coal (as shown in Table 2). The input data of ultimate and proximate analysis to Aspen Plus for the simulated coals are calculated using simple addition algorithm according to the mass percentage of macerals (as shown in Table 1). It can be seen from Table 6 that the mixed simulated coals have better thermodynamic performances concerning SOC, SCC, effective syngas and CGE than those from the parent coal and each maceral group.

Table 6 Summary of simulation results and performance indicators for the simulated coals

\begin{tabular}{|c|c|c|c|c|c|c|c|c|c|}
\hline \multirow{2}{*}{$\begin{array}{l}\text { Composition/ } \\
\text { vol \% }\end{array}$} & \multicolumn{9}{|c|}{ Simulated Coal No. } \\
\hline & 1 & 2 & 3 & 4 & 5 & 6 & 7 & 8 & 9 \\
\hline $\mathrm{CH}_{4}$ & 0.057 & 0.121 & 0.223 & 0.065 & 0.110 & 0.200 & 0.069 & 0.214 & 0.212 \\
\hline $\mathrm{H}_{2}$ & 35.38 & 34.50 & 33.94 & 35.14 & 34.56 & 32.23 & 35.03 & 33.18 & 33.08 \\
\hline $\mathrm{CO}$ & 59.38 & 60.64 & 61.28 & 59.71 & 60.55 & 62.83 & 59.86 & 61.95 & 62.05 \\
\hline $\mathrm{CO}_{2}$ & 0.806 & 0.384 & 0.206 & 0.708 & 0.420 & 0.217 & 0.660 & 0.211 & 0.212 \\
\hline $\mathrm{H}_{2} \mathrm{~S}$ & 0.209 & 0.212 & 0.214 & 0.204 & 0.207 & 0.2065 & 0.201 & 0.197 & 0.203 \\
\hline $\mathrm{COS}$ & 0.0150 & 0.0165 & 0.0171 & 0.0153 & 0.0161 & 0.0170 & 0.0152 & 0.0163 & 0.0169 \\
\hline $\mathrm{N}_{2}$ & 3.89 & 3.86 & 3.86 & 3.90 & 3.88 & 4.02 & 3.90 & 3.97 & 3.96 \\
\hline $\mathrm{Ar}$ & 0.25 & 0.251 & 0.251 & 0.251 & 0.251 & 0.26 & 0.25 & 0.255 & 0.255 \\
\hline Others & 0.013 & 0.0115 & 0.0069 & 0.0097 & 0.0079 & 0.0195 & 0.0148 & 0.0097 & 0.0141 \\
\hline Sum & 100 & 100 & 100 & 100 & 100 & 100 & 100 & 100 & 100 \\
\hline \multicolumn{10}{|c|}{ Performance evaluation } \\
\hline $\begin{array}{l}\text { Syngas flow } \\
\text { rate, } \mathrm{Nm}^{3} / \mathrm{h}\end{array}$ & 81239 & 81276 & 80414 & 80566 & 80603 & 77577 & 80598 & 79302 & 79030 \\
\hline SOC & 262.47 & 261.30 & 263.88 & 264.42 & 263.57 & 273.99 & 264.19 & 267.83 & 268.77 \\
\hline SCC & 458.29 & 456.24 & 460.75 & 461.69 & 460.20 & 478.40 & 461.30 & 467.65 & 469.28 \\
\hline $\begin{array}{l}\text { Syngas LHV, } \\
\mathrm{MJ} / \mathrm{h}\end{array}$ & 917018 & 924557 & 919349 & 910915 & 916181 & 887235 & 911988 & 906627 & 903572 \\
\hline CGE, $\%$ & 87.56 & 88.69 & 87.85 & 87.52 & 87.74 & 89.57 & 87.49 & 85.69 & 85.47 \\
\hline $\begin{array}{l}\left(\mathrm{CO}+\mathrm{H}_{2}\right) \\
\mathrm{vol} \%\end{array}$ & 94.76 & 95.14 & 95.22 & 94.85 & 95.11 & 95.06 & 94.89 & 95.13 & 95.126 \\
\hline
\end{tabular}




\subsection{Synergistic effects}

Synergistic effect indicates that the products and performances arising from the simulated coals are higher or lower than the sum of their individual maceral. When the synergistic coefficient is not equal to 1, it indicates the interactions among macerals showing an influence on the gasification performance. Table 7 shows a summary of the matrix of the synergistic coefficients calculated by Eqs. (7). It can be seen that interactions among macerals during gasification exist. The synergistic coefficients of $\mathrm{H}_{2}$ and $\mathrm{CO}$ contents are higher than 1, while those of the other gases such as $\mathrm{CO}_{2}$ and $\mathrm{N}_{2}$ are less than 1. Looking at the performance indicators, the synergistic coefficients of SOC and SCC are in the range of 0.94 to 0.97 deviating from 1.0. However, the synergistic coefficient of both the effective syngas and CGE are slightly greater than 1.0 and most of the values are centralized distribution around 1.005, indicating that the synergistic effect is not apparent.

Table 7 Summary of the matrix elements for the synergistic coefficients

\begin{tabular}{|c|c|c|c|c|c|c|c|c|c|}
\hline \multirow{2}{*}{ Composition, vol\% } & \multicolumn{9}{|c|}{ Simulated Coal. No } \\
\hline & 1 & 2 & 3 & 4 & 5 & 6 & 7 & 8 & 9 \\
\hline $\mathrm{CH}_{4}$ & 0.7324 & 1.5320 & 2.7934 & 0.7300 & 1.2634 & 1.6512 & 0.7310 & 1.7519 & 1.8751 \\
\hline $\mathrm{H}_{2}$ & 1.0063 & 1.0051 & 1.0028 & 1.0059 & 1.0062 & 1.0031 & 1.0060 & 1.0026 & 1.0030 \\
\hline $\mathrm{CO}$ & 1.0056 & 1.0108 & 1.0148 & 1.0060 & 1.0104 & 1.0074 & 1.0061 & 1.0088 & 1.0095 \\
\hline $\mathrm{CO}_{2}$ & 0.6584 & 0.3312 & 0.1837 & 0.6237 & 0.3789 & 0.2954 & 0.6040 & 0.2660 & 0.2509 \\
\hline $\mathrm{H}_{2} \mathrm{~S}$ & 0.9789 & 0.9623 & 0.9588 & 0.9797 & 0.9656 & 0.9784 & 0.9771 & 0.9736 & 0.9706 \\
\hline COS & 0.9785 & 0.9816 & 0.9760 & 1.0172 & 0.9943 & 0.9449 & 1.0199 & 1.0041 & 0.9940 \\
\hline $\mathrm{N} 2$ & 0.9773 & 0.9594 & 0.9547 & 0.9768 & 0.9645 & 0.9731 & 0.9757 & 0.9715 & 0.9687 \\
\hline $\mathrm{Ar}$ & 0.9804 & 0.9659 & 0.9583 & 0.9844 & 0.9715 & 0.9754 & 0.9805 & 0.9762 & 0.9701 \\
\hline Others & 0.5381 & 0.4899 & 0.2993 & 0.4170 & 0.3441 & 1.0202 & 0.6481 & 0.4909 & 0.6959 \\
\hline
\end{tabular}

Performance evaluation 


\begin{tabular}{lccccccccc}
\hline Syngas flow rate, $\mathrm{Nm}^{3} / \mathrm{h}$ & 1.0334 & 1.0511 & 1.0486 & 1.0242 & 1.0376 & 1.0264 & 1.0243 & 1.0294 & 1.0325 \\
SOC & 0.9621 & 0.9431 & 0.9437 & 0.9706 & 0.9553 & 0.9686 & 0.9704 & 0.9651 & 0.9616 \\
SCC & 0.9612 & 0.9431 & 0.9437 & 0.9706 & 0.9553 & 0.9686 & 0.9704 & 0.9651 & 0.9616 \\
Syngas LHV, MJ/h & 1.0387 & 1.0630 & 1.0648 & 1.0295 & 1.0477 & 1.0351 & 1.0297 & 1.0394 & 1.0434 \\
CGE, \% & 1.0573 & 1.0941 & 1.0952 & 1.0552 & 1.0751 & 1.1342 & 1.0541 & 1.0591 & 1.0657 \\
$\left(\mathrm{CO}+\mathrm{H}_{2}\right)$, vol\% & 1.0058 & 1.0087 & 1.0105 & 1.0060 & 1.0089 & 1.0059 & 1.0061 & 1.0066 & 1.0072 \\
\hline \hline
\end{tabular}

The relationships between synergistic coefficient and maceral contents for various performance indicators are investigated by using a direct three-order polynomial correlation method based on the data shown in Table 7. Fig.2 correlates the relations of synergistic coefficient with maceral contents for SOC and SCC respectively. Fig.3 illustrates the influence of maceral content on synergistic coefficients of CGE and effective syngas respectively. From Fig.2, it is clear that Vitrinite content correlates well with the synergistic coefficients of SOC and SCC respectively as their R-squares are 0.88 and 0.89 , whereas Inertinite content and Liptinite content display poor correlation with synergistic coefficients of SOC and SCC. It is noted that with the increase in Vitrinite, the synergistic coefficients of SOC and SCC exhibit an increase first then a decrease trend and the synergistic coefficients reach the maximum of 0.97 at a Vitrinite content of $40 \%$. In Fig.3, the change in Intrinite content shows a promising correlation with synergistic coefficient of CGE. However, the synergistic coefficient of effective syngas exhibits significantly better correlations with Vitrinite $(\mathrm{R}$-square= 0.736) than Initrinite $(\mathrm{R}$-square $=0.508)$ and Liptinite $(\mathrm{R}$-square $=0.115)$. It can be observed from Fig. 3 that CGE increases first and then reaches a plateau followed by an increase again at an Inertinite content of $27 \%$, while the synergistic coefficient of effective syngas decreases first to 1.006 and then slightly increases. Based on these correlations, we can quantitatively adjust and/or predict the synergistic coefficients when coal blends are used. 

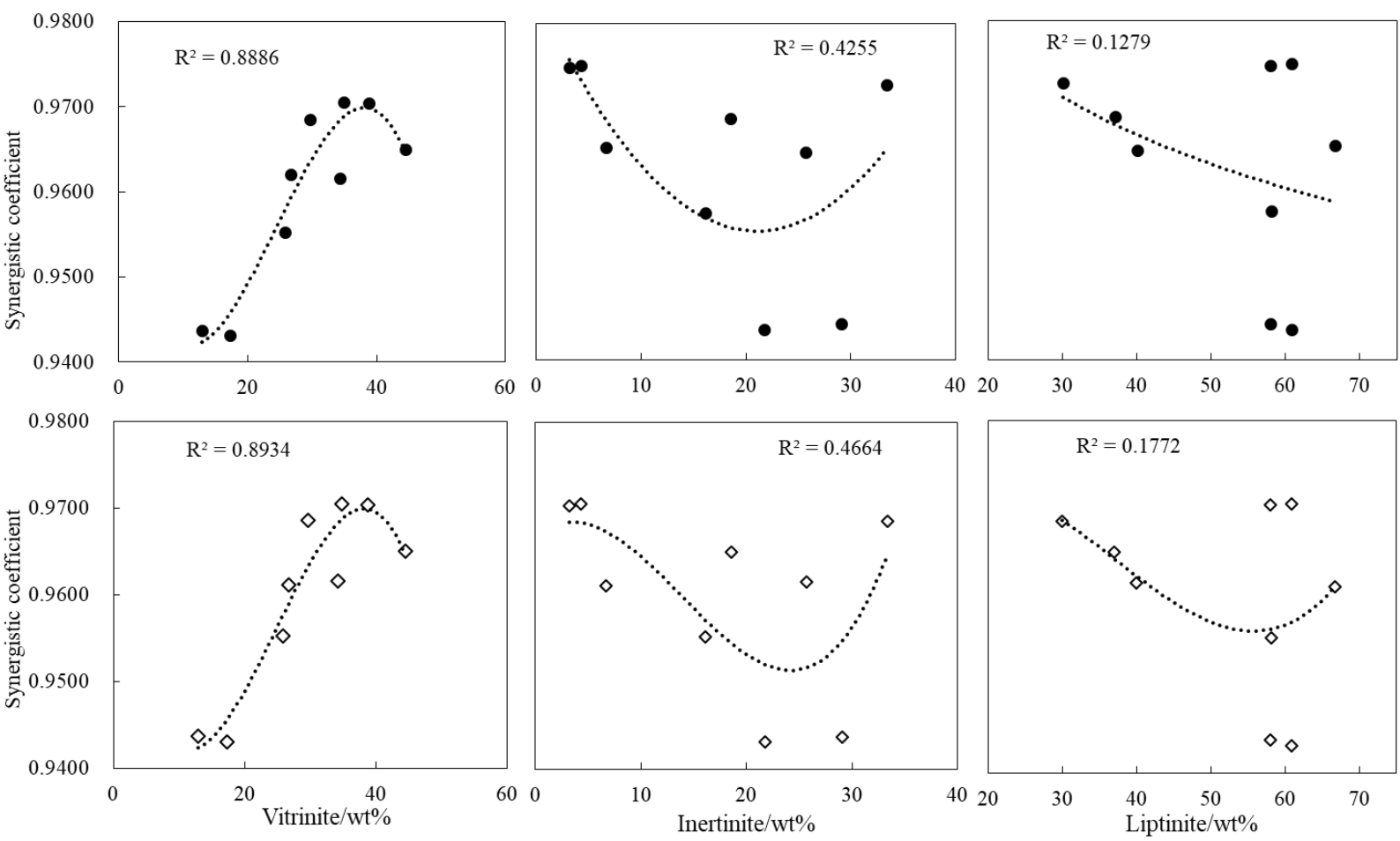

Fig.2 Relationship between the synergistic coefficient and the maceral contents for the gasification performance indicators of SOC ("•") and SCC(“॰”)
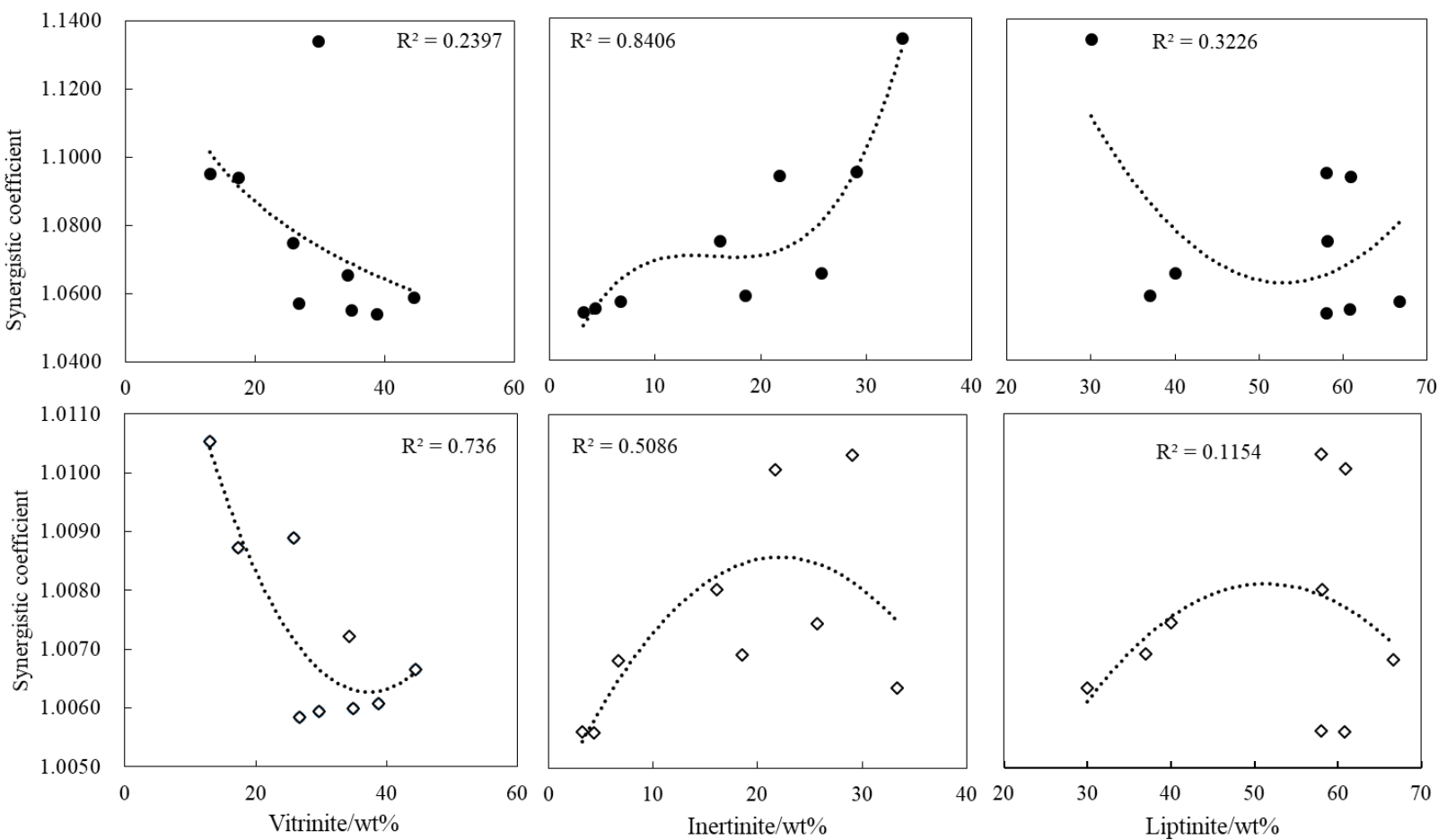

Fig.3 Relationship between the synergy effect and the maceral contents for the gasification indicators of CGE ("•") and effective syngas (" $\diamond ")$ 


\subsection{Effect of gasification temperature.}

In order to track the different gasification behaviours of parent coal and macerals under different gasification temperatures, the plot of gasification performance indicators versus operation temperature varied from 1350 to $1550{ }^{\circ} \mathrm{C}$ is displayed in Fig.4. It can be noted from Fig.4 (a) that the gasification temperature has a slightly negative influence on SOC and SCC of the coal and its macerals. However, from Fig. 4(b), with the increase in gasification temperature, the indicators of both $\mathrm{CGE}$ and $\left(\mathrm{CO}+\mathrm{H}_{2}\right) \%$ show a small addition. In addition, it can be observed that the Liptinite has the highest CGE behaviour followed by Vitrinite and Inertinite in that order. As for the effective syngas, Vitrinite has the highest effective syngas content up to 95 . vol\% at $1550^{\circ} \mathrm{C}$. The reasons behind these phenomena are mainly attributed to the endothermic reactions, such as Boudouard reaction and carbon water gas reaction, being promoted and the exothermic reaction water gas reaction being restrained at high temperature, which results in the increase in $\left(\mathrm{CO}+\mathrm{H}_{2}\right) \%$. The relative larger amount of effective syngas leads to the increase in syngas LHV and according to Eq.(1), the CGE also shows an uptrend. In accordance with Eqs.(5) and (6), the indicators SOC and SCC decrease as the effective syngas content increases.
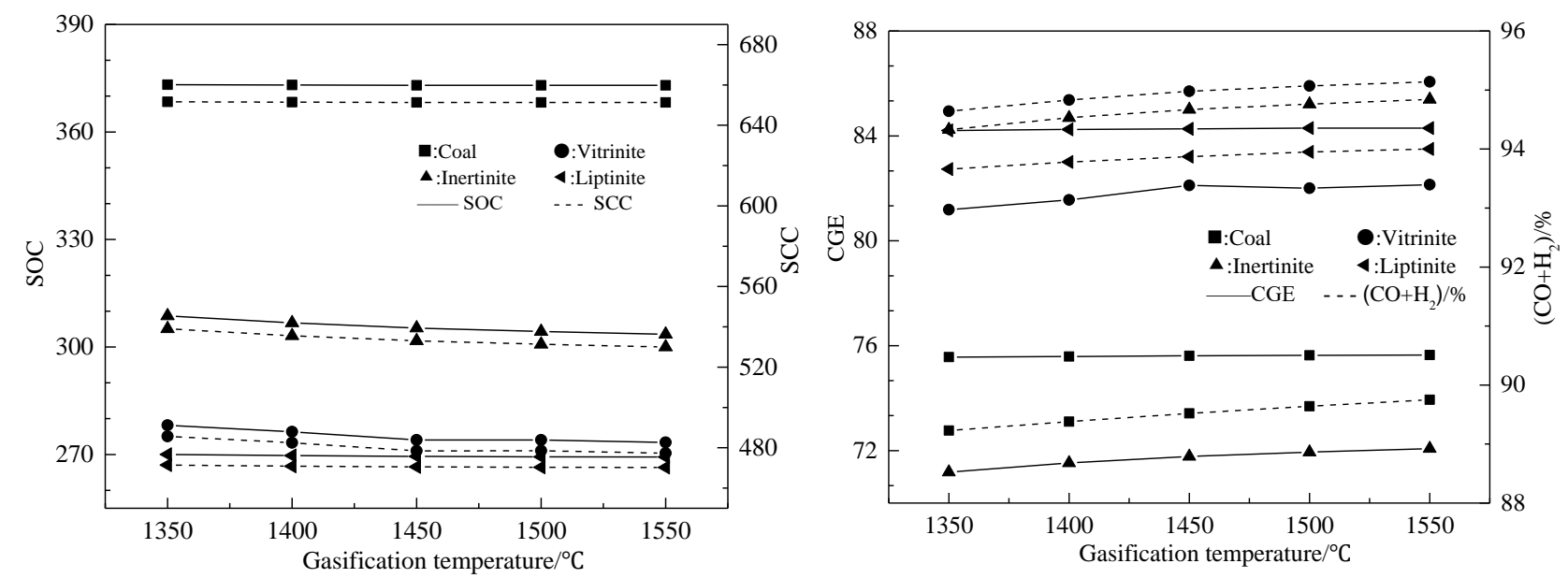
Fig.4 Effect of gasification temperature on the gasification performance parameters: (a) SOC and SCC, (b) CGE and $\left(\mathrm{CO}+\mathrm{H}_{2}\right) \%$

The effect of temperature on the synergistic coefficients of SOC, SCC, effective syngas and CGE with the variation of maceral contents is shown in Fig.5. In order to have a better quantitative comparison of the synergistic coefficients at different temperatures, three fitting curves (denoted as "FC") are presented at the temperatures of 1350,1450 and $1550{ }^{\circ} \mathrm{C}$ as shown in Fig.5. It can be observed in Fig.5 (a) and (b) that the synergistic coefficients of SOC and SCC exhibit similar properties. When gasification temperature is below $1450^{\circ} \mathrm{C}$, the impact of temperature is not obvious, whereas when gasification temperature is higher than $1450{ }^{\circ} \mathrm{C}$, the synergistic coefficient detrimental value is about 0.005 . This suggests that higher gasification temperature is favourable to the maceral interactions and leads to the decrease in oxygen and coal consumptions. It can be seen from Fig. 5(c) that the gasification temperature does not significantly affect the synergistic coefficient of CGE. Fig. 6(d) depicts a slightly fluctuating phenomenon regarding the synergistic coefficient curves at 1350 , 1450 and $1550{ }^{\circ} \mathrm{C}$. Nevertheless, the fluctuation range is limited to $0.05 \%$ demonstrating that temperature has little impact on the effective syngas content.

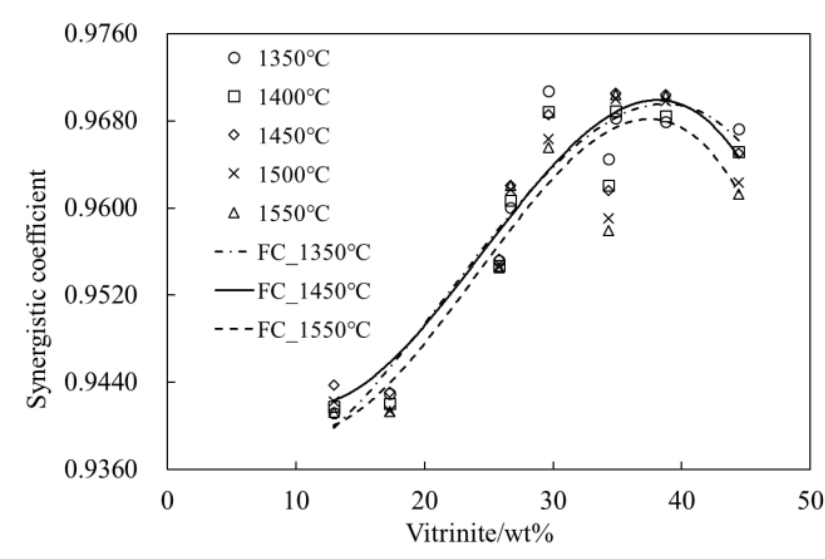

(a)

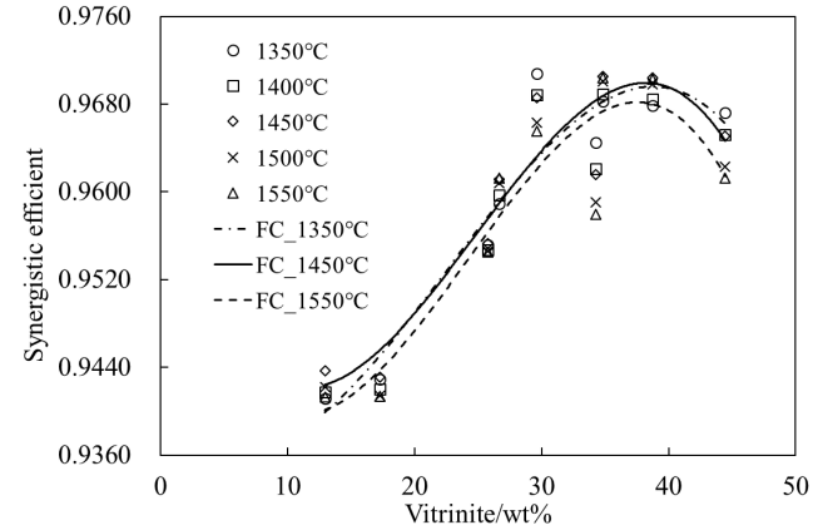

(b) 


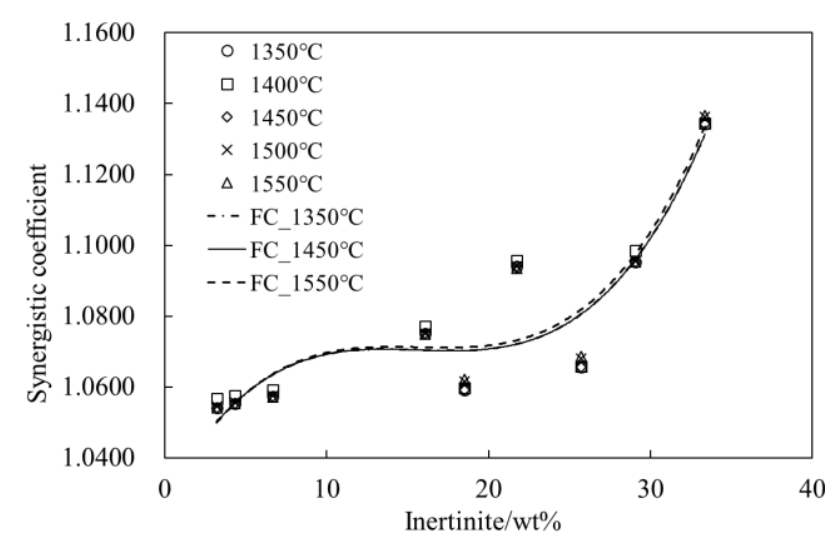

(c)

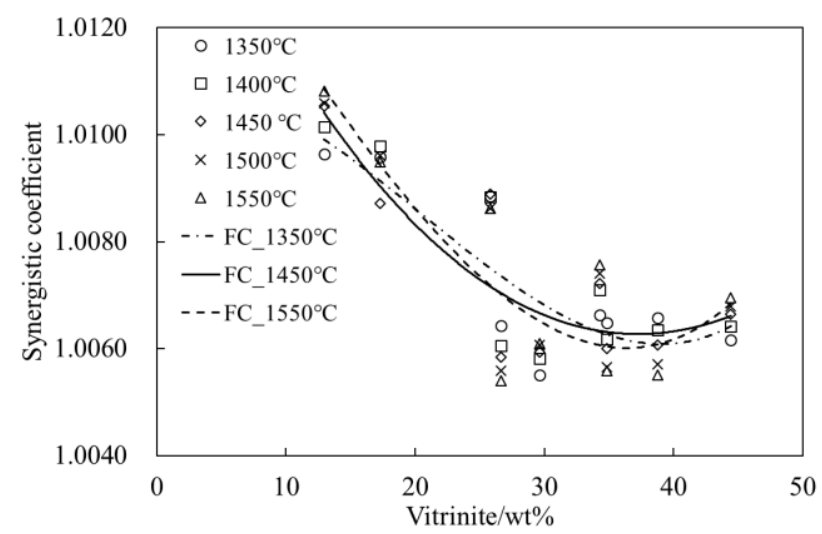

(d)

Fig.5 Effect of Vitrinite content on the synergy coefficients of (a) SOC, (b) SCC, (d) $\left(C^{2}+\mathrm{H}_{2}\right) \%$ and effect of Inertinite on synergy coefficient of CGE (c) and at different gasification temperatures

\subsection{Effect of oxygen to coal (OTC) mass ratio}

The effects of oxygen to coal mass ratio on SCC, SOC, CGE and effective syngas content of parent coal and its macerals have been studied and are shown in Fig.6. At low OTC, all the SOC values increase slightly and then increases sharply to a value of 700 when the OTC is greater than 0.65 , while the SOC values of macerals still show a relatively tiny addition increment and their maximum SOC values are from 415 to 480 at the $\mathrm{OTC}=1.1$. The $\mathrm{SCC}$ values of macerals show a decline at first and then increase for different macerals, but their variation patterns are not synchronous. The minimal SCC value of coal and its macerals are found to be $586.53 \mathrm{~kg} / \mathrm{kNm}^{3}, 478.47 \mathrm{~kg} / \mathrm{kNm}^{3}$ (Vitrinite), $468.63 \mathrm{~kg} / \mathrm{kNm}^{3}$ (Liptinite) and $481.21 \mathrm{~kg} / \mathrm{kNm}^{3}$ (Inertinite) at the OTC of $0.65,0.8,0.65$ and 0.95 respectively. Fig.6(b) presents the results of oxygen addition in the gasifier on CGE and effective syngas content. The CGE values of parent coal, Vitrinite, Inertinite and Liptinite vary from 55\% to $84 \%$ and reach their corresponding peaks at the $\mathrm{OTC}=0.65,0.8,0.95$ and 0.65 . Besides, the mole fractions of $\left(\mathrm{CO}+\mathrm{H}_{2}\right)$ go up slightly, which is illustrated by a sharp decrease at OTC of $0.65,0.8,0.95$ and 0.65 for coal, Vitrinite, Inertinite and Liptinite, respectively. The $\left(\mathrm{CO}+\mathrm{H}_{2}\right) \%$ is changed from 95 vol\% to 74 vol\%. Before the turning points of all the indicators for each feedstock, the flow rates of 
oxygen that is fed into the gasifier could not fully covert carbon into syngas, thus the increase of oxygen brings the increase of effective syngas, CGE and SOC. After the turning points, the oxygen flow rate exceeds the stoichiometric requirements of gasification, thus the addition of oxygen leads to the combustion of syngas and results in the drop of the effective syngas and CGE. Besides, the reason for different turning point values of coal and its macerals is mainly attributed to the discrepancies of the elementary composition of macerals and coal.

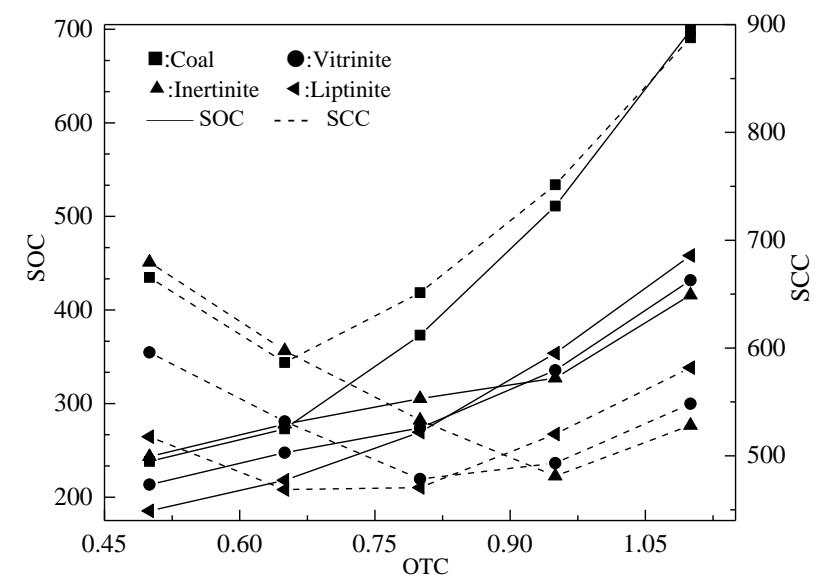

(a)

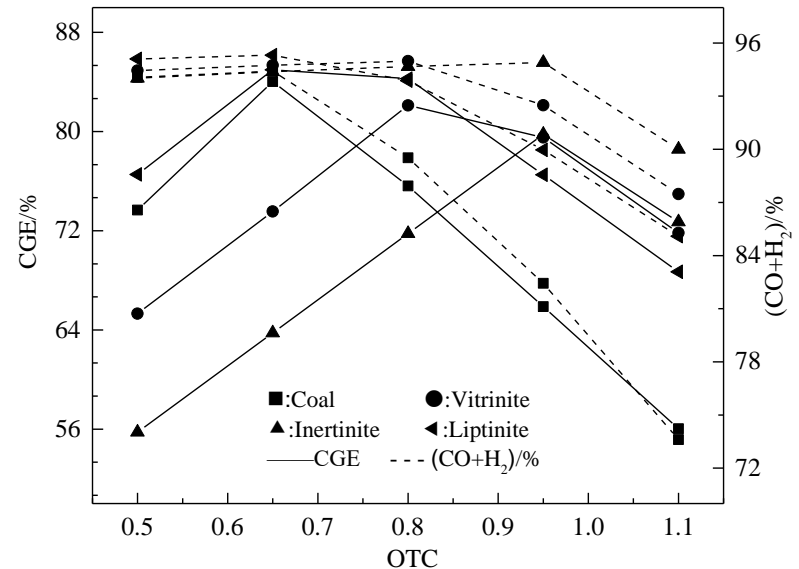

(b)

Fig.6 Effect of oxygen to coal mass fraction on the gasification performance parameters: (a) SOC and SCC, (b) CGE and $\left(\mathrm{CO}_{+} \mathrm{H}_{2}\right) \%$ for coal and its maceral components of Vitrinite, Inertinite and Liptinite

Fig.7 reveals the effect of maceral contents on the synergistic coefficients of SOC, SCC, CGE and effective syngas at various OTC varying from 0.5 to 1.1 . Besides, the correlation lines at the OTC of 0.5, 0.8 and 1.1 are also shown in those figures for better comparisons. It is denoted from Fig.7 (a) and (b) that the synergistic coefficients of SCC and SOC exist a minimum value which is found to be varied from 0.94 to 0.97 when OTC equals to 0.8 . However, when OTC changes from 0.5 to 1.1 , the synergistic coefficients of SCC and SOC increase initially and decrease afterwards. From Fig. 7(c), it can be clearly seen that the synergistic coefficient of CGE maintains the highest at OTC $=0.8$ than that at any other OTC values in the whole range of Inertinite variation. Fig.7(d) shows that the 
synergistic coefficient is enhanced at the OTC of 0.8 . However, the coefficient is lower than 1 at OTC $>0.8$, which indicates that interactions among macerals exist a slightly mutual inhibition effect.

It can be concluded from Fig.7 that OTC is greater than 0.8, the interactions among macerals are no longer in existence or even existing inhibition effect and at the OTC $=0.8$, the synergistic coefficients of SOC, SCC, CGE and effective syngas achieve maximum efficiencies.

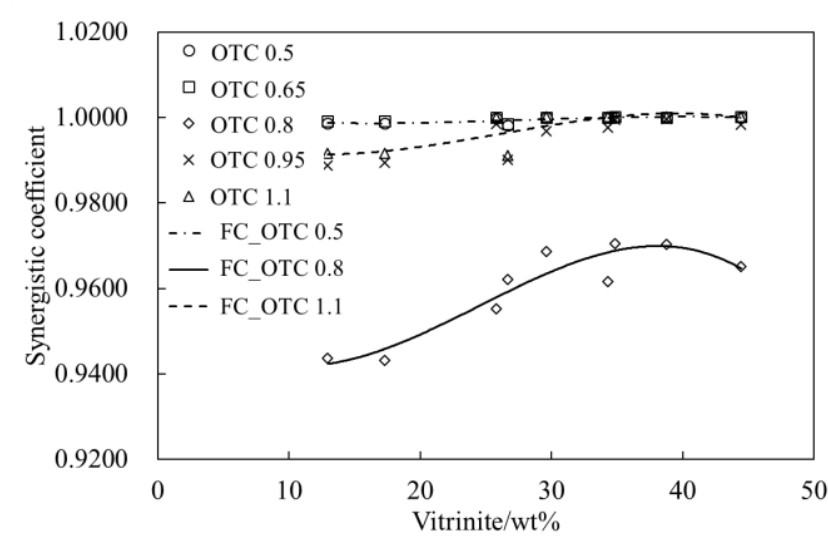

(a)

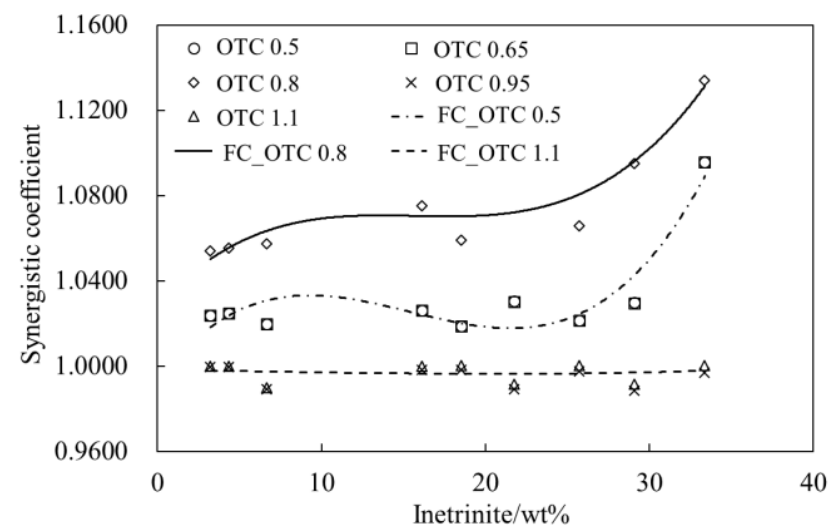

(c)

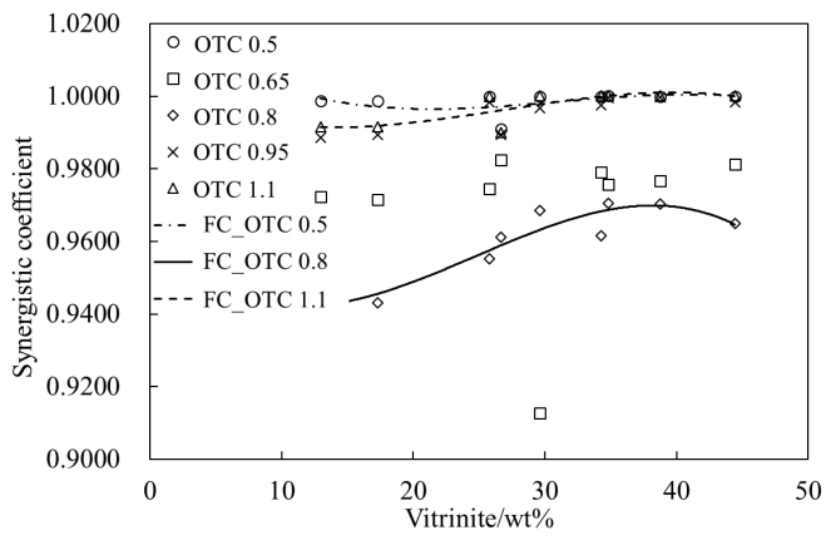

(b)

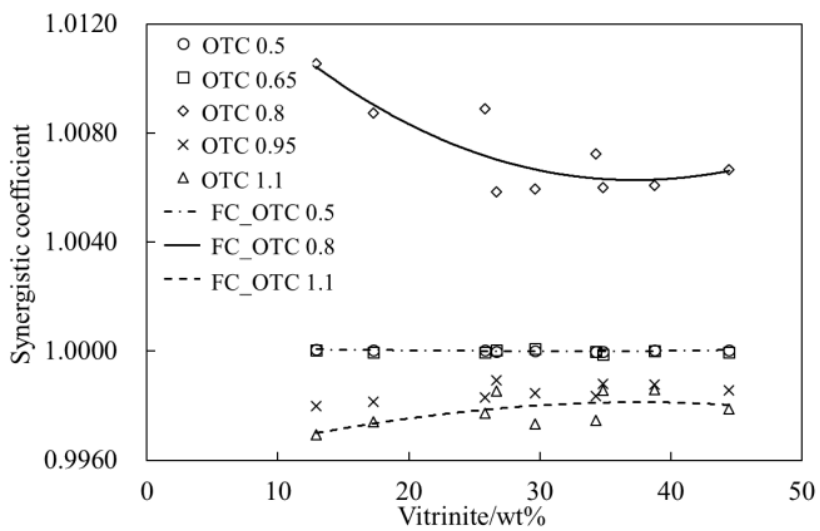

(d)

Fig.7 Effect of vitrinite content on the synergistic coefficients of (a) SOC, (b) SCC, (d) (CO+H2)\% and effect of inertinite on the synergistic coefficient of CGE (c) and at different OTC

\subsection{Effect of steam to coal (STC) mass fraction.}

Fig.8 shows how the variation in performance indicators, such as SOC, SCC, CGE and effective syngas content of parent coal and its macerals with the increase of STC in the range of 0.01 to 0.16. 
As can be observed from Fig.8(a), both the SOC and SCC of coal and Liptinite are not sensitive to the addition of steam, while both the SOC and SCC regarding Vitrinite and Inertinite decrease. Fig.8(b) describes that the CGE values of both coal and Liptinite remain level, whereas the CGE values of both Vitrinite and Inertinite go up steadily. The $\left(\mathrm{CO}+\mathrm{H}_{2}\right)$ contents of both coal and Liptinite shows a gradual decline while both Vitrinite and Inertinite show a moderate increase. The injection of steam in the gasifier favours the reactions, such as $\mathrm{C}+\mathrm{H}_{2} \mathrm{O}=\mathrm{CO}+\mathrm{H}_{2}$ and $\mathrm{CO}+\mathrm{H}_{2} \mathrm{O}=\mathrm{CO}_{2}+\mathrm{H}_{2}$, which enhance the formation of $\mathrm{CO}$ and $\mathrm{H}_{2}$. Therefore, the effective syngas content and CGE of Vitrinite and Inertinite increase and SOC and SCC referring the Eqs. (5) and Eqs. (6). However, the behaviours of Coal and Liptinite do not comply with this explanation, this is mainly because that the composition differences between parent coal and its macerals. Specifically, the carbon content of both coal and Liptinite is lower than that of Vitrinite and Inertintie, by the addition of steam has little positive impact on the carbon water reaction for carbon has already been reacted completely with oxygen and with the moisture water in coal. Although the effective syngas of coal and Liptinite show a declining trend, the total flow rates of syngas for those feedstocks exhibit a slightly increasing trend, which results in the constant properties of SOC, SCC and CGE.

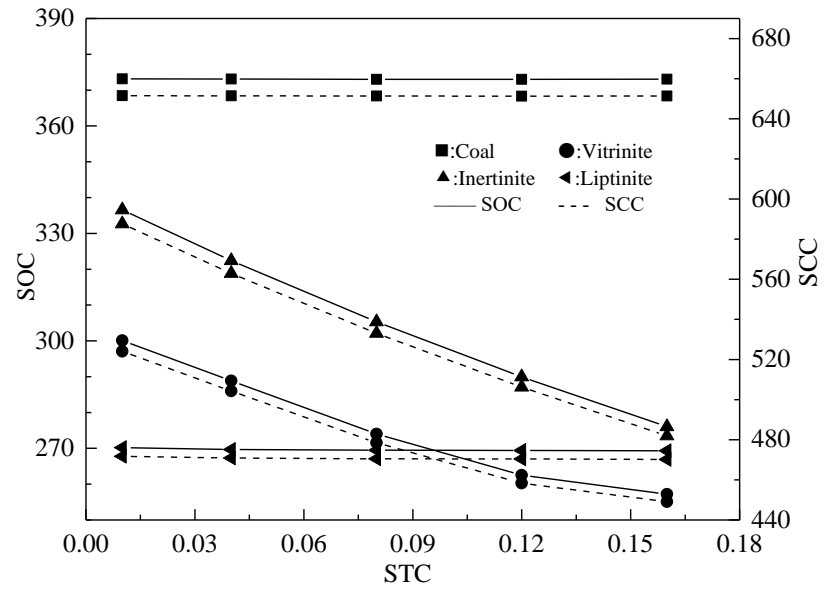

(a)

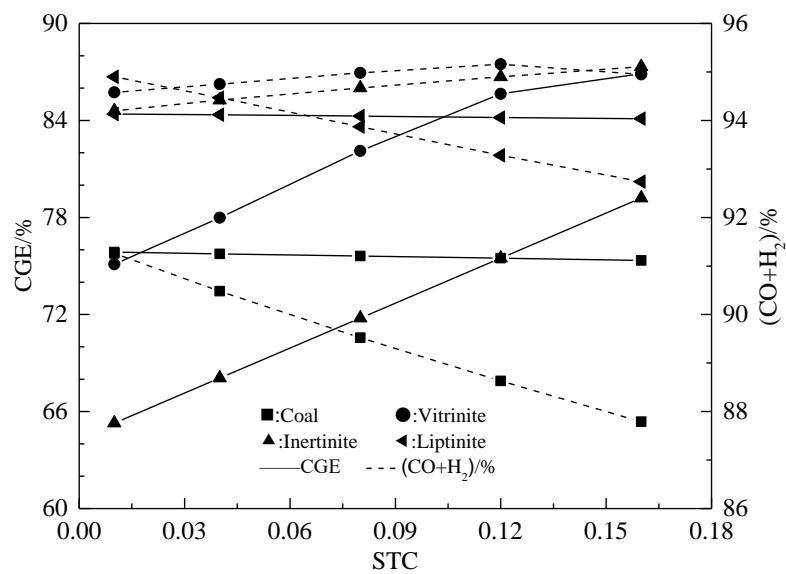

(b) 
Fig.8 Effect of steam to coal mass fraction on the gasification performance parameters: (a) SOC and SCC, (b) CGE and $\left(\mathrm{CO}+\mathrm{H}_{2}\right) \%$ for coal and its maceral components of Vitrinite, Inertinite and Liptinite

The variations of synergistic coefficients of SOC, SCC, CGE and effective syngas at different STC values in the range of 0.01 to 0.16 are plotted in Fig.9. The fitting curves at the STC of 0.01, 0.08 and 0.16 are presented in this figure. It can be observed from Fig. 9 that the synergistic coefficients achieve their extremums at $\mathrm{STC}=0.8$, which indicates that the promoted interactions among macerals realize the maximum function.

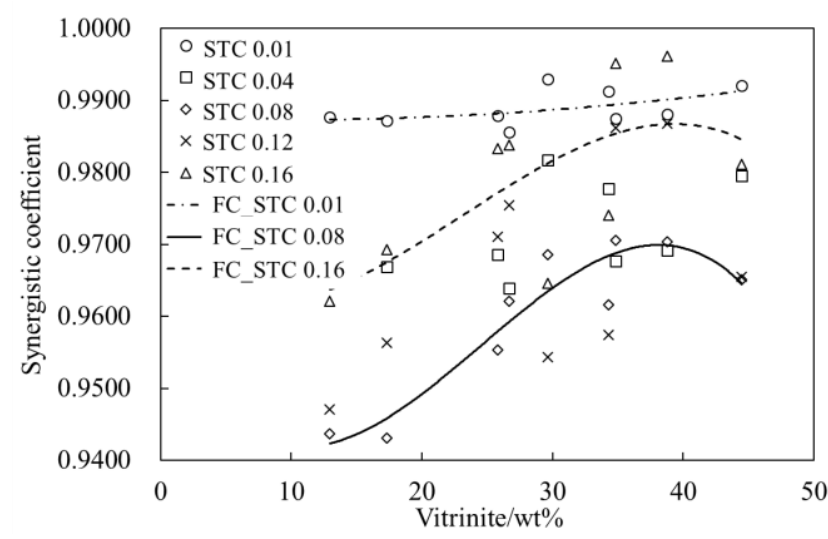

(a)

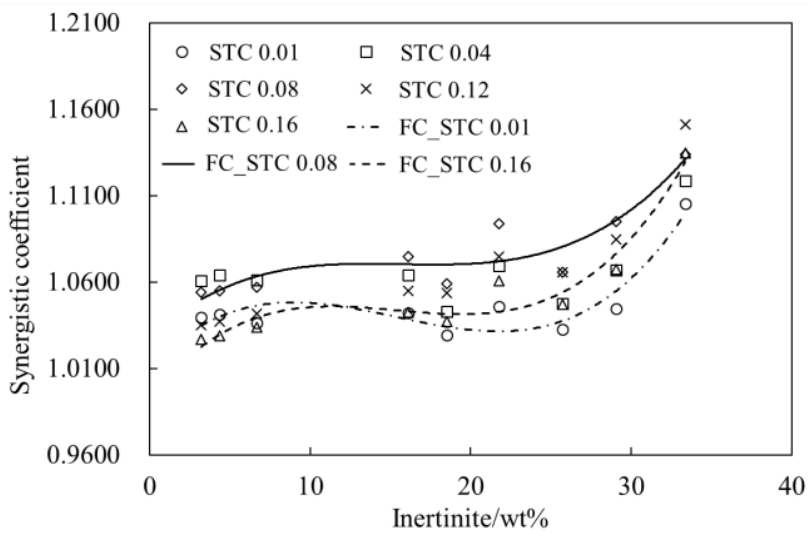

(c)

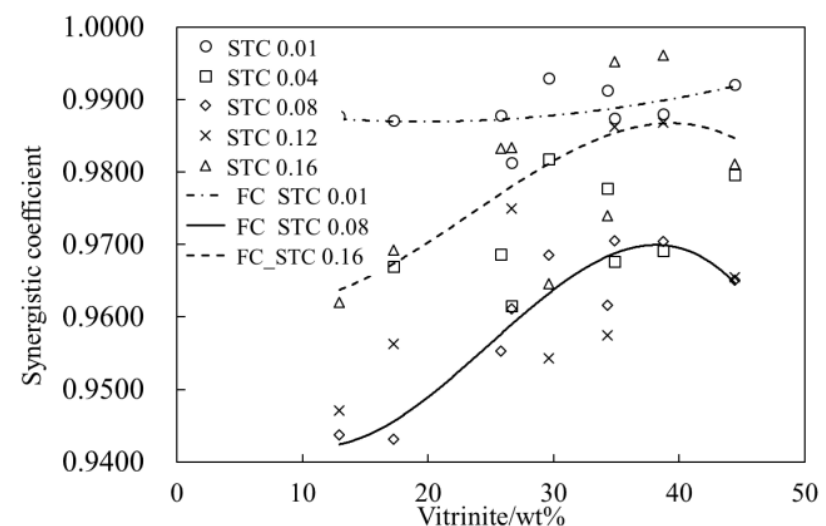

(b)

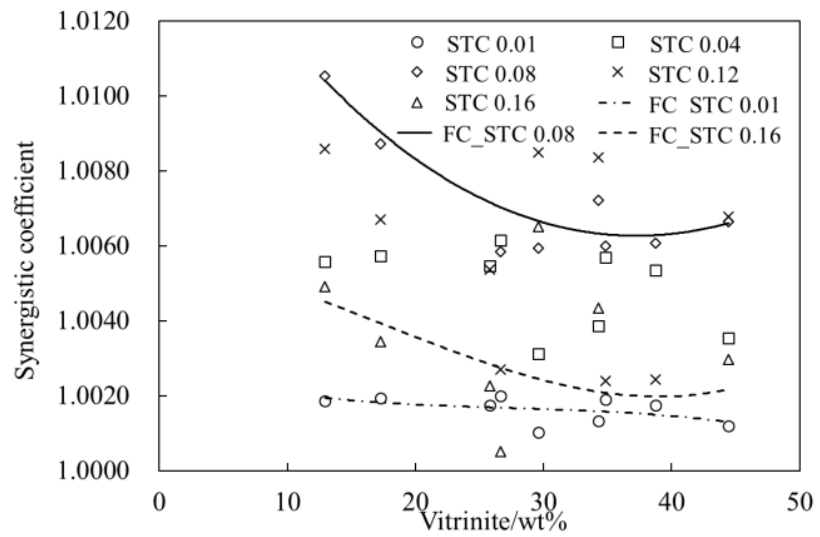

(d)

Fig.9 Effect of vitrinite content on the synergy coefficients of : (a) SCC, (b) SOC , (d) $\left(C O+\mathrm{H}_{2}\right) \%$ and effect of inertinite on synergy coefficient of CGE (c) and at different STC 
Due to the complex physical and chemical properties of coal, it is hard to prove the existence of synergistic effect between macerals gasification directly. The present work is to compare the performance indicators from simulated coals and the calculated values based on the weight of the macerals assuming additive properties apply. According to the previous studies [19, 21, 42-44], the reasons for synergistic effect among macerals might be concluded as below. Liptinite holds the highest $\mathrm{H} / \mathrm{C}$ followed by Vitrinite and Inertinite, when macerals are blended in gasifier, a large amount of hydrogen donors $(\mathrm{H}$ and $\mathrm{OH}$ radicals) produced from Liptinite involve in the decomposition of the remained macerals and suppress re-polymerization and crosslinking reactions of free radicals during gasification [43, 44]. On the other hand, based on the works of $[19,21,42]$, because Liptinite and Vitrinite occupy more hydrocarbon aliphatic and lower aliphatic, they are prone to produce more metaplast, which acts as the hydrogen donor solvent and stabilize more rupture fragments and free radicals produced by the Inertinite, resulting in enhancement of gasification performances.

\section{Conclusions}

This study revealed the gasification performance of a coal and its corresponding macerals and the interactions among macerals based on Aspen Plus process modelling. For the first time, the synergistic coefficient was quantified to show the extent of the interactions among macerals during gasification. Sensitivity analyses were conducted to demonstrate the effects of gasification temperature, oxygen to coal mass ratio and steam to coal mass ratio on the gasification performance of coal and individual macerals and also on the synergistic coefficients. The main conclusions are: 
1. The synergistic coefficients of SOC and SCC of the simulated coals were in the range of 0.94 to 0.97 whereas the synergistic coefficient of CGE was from 1.05 to 1.13 and that of the $\left(\mathrm{CO}+\mathrm{H}_{2}\right) \%$ varied from 1.005 to 1.01 .

2. The synergistic coefficients of SOC, $\mathrm{SCC}$ and $\left(\mathrm{CO}+\mathrm{H}_{2}\right) \%$ had a very strong correlation with Vitrinite contents while the CGE showed a good correlation with Inertinite.

3. The synergistic coefficient increases slightly with the increase in gasification temperature. The optimal synergistic coefficient was found out to be at $\mathrm{OTC}=0.8$ and $\mathrm{STC}=0.8$.

\section{Acknowledgments}

This work is supported by the National Key Research and Development Program of China (2017YFB0602600). The University of Nottingham Ningbo China is acknowledged for providing scholarship to the first author.

\section{References}

[1] IEA., 2017, "Market Series Report: Coal 2017."

[2] Wang, T., and Stiegel, G. J., 2016, Integrated gasification combined cycle (IGCC) technologies, Woodhead Publishing.

[3] Wu, H., Li, S., and Gao, L., 2017, "Exergy destruction mechanism of coal gasification by combining the kinetic method and the energy utilization diagram," Journal of Energy Resources Technology, 139(6), p. 062201.

[4] Wang, D., Li, S., Gao, L., Wu, H., and Jin, H., 2018, "Novel coal-steam gasification with a thermochemical regenerative process for power generation," Journal of Energy Resources Technology, 140(9), p. 092203.

[5] Zhao, H., Mu, X., Zheng, C., Liu, S., Zhu, Y., Gao, X., and Wu, T., 2019, "Structural defects in 2D MoS2 nanosheets and their roles in the adsorption of airborne elemental mercury," Journal of hazardous materials, 366, pp. 240-249.

[6] Wu, T., Gong, M., Lester, E., Wang, F., Zhou, Z., and Yu, Z., 2007, "Characterisation of residual carbon from entrained-bed coal water slurry gasifiers," Fuel, 86(7-8), pp. 972-982. 
[7] Maurstad, O., "An Overview of Coal based Integrated Gasification Combined Cycle (IGCC," Proc. Technology; MIT LFEE 2005-002 WP; Laboratory for Energy and the Environment, Massachusetts Institute of Technology, Citeseer.

[8] Guo, X., Dai, Z., Gong, X., Chen, X., Liu, H., Wang, F., and Yu, Z., 2007, "Performance of an entrained-flow gasification technology of pulverized coal in pilot-scale plant," Fuel processing technology, 88(5), pp. 451-459.

[9] Zhu, Y., Somasundaram, S., and Kemp, J. W., 2010, "Energy and exergy analysis of gasifierbased coal-to-fuel systems," Journal of Energy Resources Technology, 132(2), p. 021008. [10] Scott, A. C., 2002, "Coal petrology and the origin of coal macerals: a way ahead?," International Journal of Coal Geology, 50(1-4), pp. 119-134.

[11] Wu, T., Lester, E., and Cloke, M., 2006, "Advanced automated char image analysis techniques," Energy and Fuels, 20(3), pp. 1211-1219.

[12] Wu, T., Lester, E., and Cloke, M., 2006, "A burnout prediction model based around char morphology," Energy and Fuels.

[13] Zhao, Y., Hu, H., Jin, L., He, X., and Wu, B., 2011, "Pyrolysis behavior of vitrinite and inertinite from Chinese Pingshuo coal by TG-MS and in a fixed bed reactor," Fuel processing technology, 92(4), pp. 780-786.

[14] Sun, Q., Li, W., Chen, H., and Li, B., 2003, "The variation of structural characteristics of macerals during pyrolysis

[15] Huang, Y.-H., Yamashita, H., and Tomita, A., 1991, "Gasification reactivities of coal macerals," Fuel processing technology, 29(1-2), pp. 75-84.

[16] Megaritis, A., Messenböck, R., Chatzakis, I., Dugwell, D., and Kandiyoti, R., 1999, "Highpressure pyrolysis and $\mathrm{CO} 2$-gasification of coal maceral concentrates: conversions and char combustion reactivities," Fuel, 78(8), pp. 871-882.

[17] Sun, Q., Li, W., Chen, H., and Li, B., 2004, "The CO2-gasification and kinetics of Shenmu maceral chars with and without catalyst," Fuel, 83(13), pp. 1787-1793.

[18] Wang, J.-H., and Chang, L.-P., 2015, "Pyrolysis and gasification reactivity of several typical Chinese coals and their macerals," Energy Sources, Part A: Recovery, Utilization, and Environmental Effects, 37(6), pp. 670-678.

[19] Sun, Q., Li, W., and Li, B., 2002, "The synergistic effect between macerals during pyrolysis," Fuel, 81(7), pp. 973-974.

[20] Chang, H., Deng, H., Yang, Q., Du, S., Hu, F., and Jia, C., 2017, "Interaction of vitrinite and inertinite of Bulianta coal in pyrolysis," Fuel, 207, pp. 643-649.

[21] Sun, Q., Li, W., Chen, H., and Li, B., 2007, "The synergistic effect between coal macerals during hydropyrolysis," Energy Sources, Part A, 29(2), pp. 125-132.

[22] Zubkova, V., Kosewska, M., Wrobelska, K., and Prezhdo, V., 2005, "Synergetic effects during carbonisation of Polish orthocoking coals," Fuel processing technology, 86(8), pp. 899-912.

[23] Xiangdong, K., Zhong, W., Wenli, D., and Feng, Q., 2013, "Three stage equilibrium model for coal gasification in entrained flow gasifiers based on aspen plus," Chinese journal of chemical engineering, 21(1), pp. 79-84.

[24] Zhao, Y., Yu, B., Wang, B., Zhang, S., and Xiao, Y., 2018, "Heat integration and optimization of direct-fired supercritical $\mathrm{CO} 2$ power cycle coupled to coal gasification process," Applied Thermal Engineering, 130, pp. 1022-1032. 
[25] Mallick, D., Buragohain, B., Mahanta, P., and Moholkar, V. S., 2018, "Gasification of Mixed Biomass: Analysis Using Equilibrium, Semi-equilibrium, and Kinetic Models," Coal and Biomass Gasification, Springer, pp. 223-241.

[26] Becker, W. L., Penev, M., and Braun, R. J., 2019, "Production of Synthetic Natural Gas From Carbon Dioxide and Renewably Generated Hydrogen: A Techno-Economic Analysis of a Power-toGas Strategy," Journal of Energy Resources Technology, 141(2), p. 021901.

[27] Martelli, E., Kreutz, T., Carbo, M., Consonni, S., and Jansen, D., 2011, "Shell coal IGCCS with carbon capture: conventional gas quench vs. innovative configurations," Applied energy, 88(11), pp. 3978-3989.

[28] Higman, C., and van der Burgt, M., 2008, "Gasification. 2nd."

[29] Collot, A.-G., 2006, "Matching gasification technologies to coal properties," International Journal of Coal Geology, 65(3-4), pp. 191-212.

[30] Fernandez-Lopez, M., Pedroche, J., Valverde, J., and Sanchez-Silva, L., 2017, "Simulation of the gasification of animal wastes in a dual gasifier using Aspen Plus®," Energy Conversion and Management, 140, pp. 211-217.

[31] Zhu, L., Jiang, P., and Fan, J., 2015, "Comparison of carbon capture IGCC with chemicallooping combustion and with calcium-looping process driven by coal for power generation," Chemical Engineering Research and Design, 104, pp. 110-124.

[32] Al-Zareer, M., Dincer, I., and Rosen, M. A., 2018, "Influence of Selected Gasification Parameters on Syngas Composition From Biomass Gasification," Journal of Energy Resources Technology, 140(4), p. 041803.

[33] Fan, J., Hong, H., Zhu, L., Jiang, Q., and Jin, H., 2017, "Thermodynamic and environmental evaluation of biomass and coal co-fuelled gasification chemical looping combustion with CO2 capture for combined cooling, heating and power production," Applied energy, 195, pp. 861-876. [34] Ogidiama, O. V., Zahra, M. A., and Shamim, T., 2018, "Techno-Economic Analysis of a Carbon Capture Chemical Looping Combustion Power Plant," Journal of Energy Resources Technology, 140(11), p. 112004.

[35] Xie, K.-C., 2015, Structure and Reactivity of Coal: A Survey of Selected Chinese Coals, Springer.

[36] JIAO, S., 2002, "Choice of gasifier's pattern for IGCC power plant," Gas Turbine Technology, 15(2), pp. 5-14.

[37] Li, S., Jin, H., and Gao, L., 2013, "Cogeneration of substitute natural gas and power from coal by moderate recycle of the chemical unconverted gas," Energy, 55, pp. 658-667.

[38] Duan, W., Yu, Q., Zuo, Z., Qin, Q., Li, P., and Liu, J., 2014, "The technological calculation for synergistic system of BF slag waste heat recovery and carbon resources reduction," Energy Conversion and Management, 87, pp. 185-190.

[39] Seo, H.-K., Park, S., Lee, J., Kim, M., Chung, S.-W., Chung, J.-H., and Kim, K., 2011, "Effects of operating factors in the coal gasification reaction," Korean Journal of Chemical Engineering, 28(9), p. 1851.

[40] Channiwala, S., and Parikh, P., 2002, "A unified correlation for estimating HHV of solid, liquid and gaseous fuels," Fuel, 81(8), pp. 1051-1063.

[41] Bilgen, S., Kaygusuz, K., and Sari, A., 2004, "Second law analysis of various types of coal and woody biomass in Turkey," Energy Sources, 26(11), pp. 1083-1094.

[42] Elliott, M. A., 1981, "Chemistry of coal utilization. Second supplementary volume." 
[43] Edreis, E. M. A., Luo, G., Li, A., Xu, C., and Yao, H., 2014, "Synergistic effects and kinetics thermal behaviour of petroleum coke/biomass blends during $\mathrm{H} 2 \mathrm{O}$ co-gasification," Energy Conversion and Management, 79, pp. 355-366.

[44] Edreis, E. M. A., Luo, G., Li, A., Chao, C., Hu, H., Zhang, S., Gui, B., Xiao, L., Xu, K., Zhang, P., and Yao, H., 2013, "CO2 co-gasification of lower sulphur petroleum coke and sugar cane bagasse via TG-FTIR analysis technique," Bioresource Technology, 136, pp. 595-603. 